\title{
Two new species of the genus Carpelimus Leach, 1819 (Coleoptera, Staphylinidae, Oxytelinae) from Madagascar
}

\section{Ава новых вида рода Carpelimus Leach, 1819 (Coleoptera, Staphylinidae, Oxytelinae) с MaАaгаскара}

\author{
M.Yu. Gildenkov \\ М.Ю. Гильденков
}

\begin{abstract}
Department of Ecology and Chemistry, Smolensk State University, Przhevalskogo Str. 4, Smolensk 214000 Russia. E-mail: mgildenkov@mail.ru.

Кафедра экологии и химии, Смоленский государственный университет, ул. Пржевальского 4, Смоленск 214000 Россия.
\end{abstract}

Key words: Coleoptera, Staphilinidae, Carpelimus, new species, Tropical Africa, Madagascar.

Ключевые слова: Coleoptera, Staphilinidae, Carpelimus, новый вид, Тропическая Африка, Мадагаскар.

\begin{abstract}
Two new species of rove beetles, Carpelimus (Trogophloeus) mahamasiensis Gildenkov, sp.n. and Carpelimus (Trogophloeus) banari Gildenkov, sp.n., are described from Madagascar.
\end{abstract}

Резюме. Описано два новых вида Carpelimus (Trogophloeus) mahamasiensis sp.n. и Carpelimus (Trogophloeus) banari sp.n. с Мадагаскара.

\section{Introduction}

The fauna of Carpelimus in tropical Africa, including Madagascar, can be reliably regarded as well studied [Gildenkov, 2007a, b; 2011; 2012; 2013a, ; 2015; 2019]. The ability to fly, which is well developed in Carpelimus, and the use of other forms of dispersal are the reasons that only one species, Carpelimus (Trogophloeus) malgaceus (Fauvel, 1904), was long thought to be endemic for Madagascar; this species was later reported also for Mozambique [Gildenkov, 2015]. The discovery of two new species in Madagascar, which are unknown in other regions, is of significant interest.

\section{Material and methods}

This paper is based on the specimens deposited in the following collections: BMNH - British Museum of Natural History (London, Great Britain); cJJ — private collection of J. Janák (Rtyně nad Bílinou, Czech Republic); cMG — private collection of M. Gildenkov (Smolensk, Russia); cPB - private collection of Petr Baňař (Strážnice, Czech Republic); MHNG - Museum d'Histoire Naturelle Geneva (Switzerland); MMBC Moravian Museum in Brno Collection (Czech Republic); NHMW - Naturhistorisches Museum Wien (Austria). In the present study, standard methods were used for the taxonomic research of insects; the preparations were made on an MBS-10 binocular microscope. The genital preparations were processed using $10 \% \mathrm{KOH}$ and then fixed in euparal. In the descriptions and diagnoses giving the length to width ratio for the head, pronotum, and elytra, the following standard units were used: 7 standard units $=0.1 \mathrm{~mm}$; thus, 1 standard unit constitutes about $0.0143 \mathrm{~mm}$. The labels are given in the original transcription. Photographs were taken with a Canon EOS 5D Mark III camera and a Canon MP-E $65 \mathrm{~mm}$ objective using the extended focus technology.

\section{Results \\ Carpelimus (Trogophloeus) mahamasiensis Gildenkov, sp.n. \\ Figs 1, 2, 5-7.}

Material. Holotype $\left(O^{7}\right)$ : Madagascar «AKR/Jan. 2016 | N MADAGASCAR Mahamasina vill. env. light trap 26.1.2016; P. Baňař lgt.» (MMBC). Paratypes: $50^{7} 0^{7}, 2$ O 9 , 36 ex. «AKR/ Jan. 2016 | N MADAGASCAR Mahamasina vill. env. light trap 26.1.2016; P. Baňař lgt.» (MMBC; 2 ex. - BMNH; 2 ex. MHNG; 2 ex. - NHMW; $20^{7} 0^{7}, 119,4$ ex. - cMG); 2 우 «MADAGASCAR 1996 Antsiranana prov. Ankarana Ambondromifehy Ivo Jeniš leg. 5-6. XII» «COLLECTIO Jiří JANÁK» (cJJ).

Description. Holotype. Length $1.8 \mathrm{~mm}$. Body dark brown, legs and antennal bases yellow brown; antennae darkened toward apex to dark brown. Integument rather shining, body with short, light-coloured hairs.

Head transverse, with a wide base, ratio of its length (from posterior margin of head to anterior margin of clypeus) to maximum width about 16:25. Neck constriction prominent. Eyes small, slightly convex. Temples well-developed, round, eye diameter in dorsal view about equal to temple length. Head about as wide across eyes as across temples (Figs. 1,2). Head surface with quite distinct, fine and dense punctation on rather densely shagreened background. Puncture diameter slightly smaller than eye facet, distances between punctures slightly smaller than their diameter, interspaces shagreened, slightly shining. Antennae rather short, antennal segments 13 elongate; segments 4-5 about as long as wide; segments 6-7 slightly transverse; segments 8-10 transverse; segment 11 elongate, conical (Figs 1, 2). 

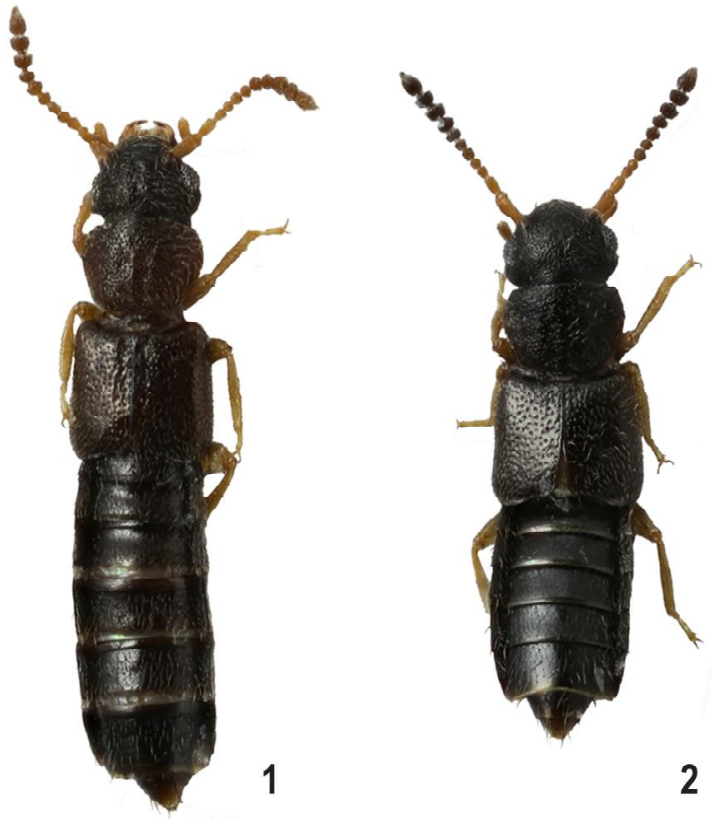

1

2

Figs 1-2. Carpelimus (Trogophloeus) mabamasiensis sp.n., dorsal view: 1 - holotype, male; 2 - paratype.

Pис. 1-2. Carpelimus (Trogophloeus) mahamasiensis sp.n., вид сверху: 1 - глотип, самец; 2 - паратип.

Pronotum widest about 2/3 its length from base, then narrowed. Lateral margins straight from base, then smoothly rounded (Figs. 1, 2). Ratio of pronotum length to its maximum width about 20:26. Surface of pronotum with quite distinct, fine and dense punctation on rather densely shagreened background. Puncture diameter slightly smaller than eye facet, distances between punctures slightly smaller than their diameter, interspaces shagreened, slightly shining. Pronotal disc with 1 pair of rather weak, symmetrical, longitudinal,

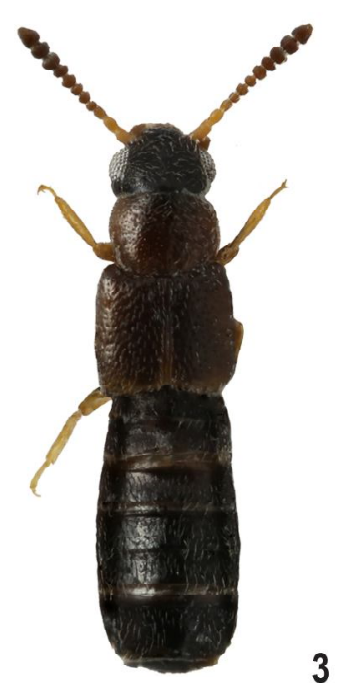

3

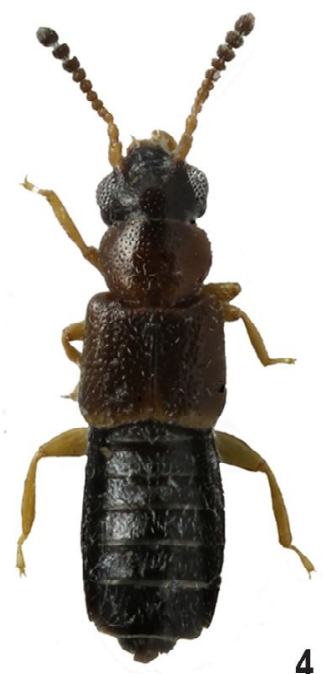

4
Figs 3-4. Carpelimus (Trogophloeus) banari sp.n., dorsal view: 3 - holotype, male; $4-$ paratype.

Pис. 3-4. Carpelimus (Trogophloeus) banari sp.n., сверху: 3 - голотип, самец; 4 - паратип. bean-shaped depressions separated by narrow, rather shining medial ridge lacking punctation (Figs 1,2).

Ratio of length of elytra to their combined width about 30:32. Surface of elytra with distinct, rather large and dense punctation. Puncture diameter slightly larger than eye facet. Distances between punctures slightly smaller than their diameter, interspaces smooth, rather shining (Figs 1, 2).

Abdomen delicately shagreened.

Aedeagus of characteristic structure (Figs 5, 6).

Female. Sexual dimorphism absent, female morphologically similar to male.

Spermatheca of characteristic structure (Fig. 7).

Differential diagnosis. The new species is somewhat similar in body size, colouration, body proportions and punctation patterns on elytra to Carpelimus (Trogophloeus) capitous Gildenkov, 2013. It can clearly be distinguished by distinct punctation on the head and pronotum and the structure (Figs. 5-7) of the spermatheca and aedeagus [Gildenkov, 2013a: P.273: fig.1: 1; Gildenkov, 2015: P.383: fig.17: 16, 17].

Distribution. North of Madagascar.

Etymology. The new species is named after its collection locality.

\section{Carpelimus (Trogophloeus) banari \\ Gildenkov, sp.n.}

Figs 3, 4, 8-10.

Material. Holotype (O'): Madagascar «AKR/Jan. 2016 | N MADAGASCAR Mahamasina vill. env. light trap 26.1.2016; P. Baňař lgt.» (MMBC). Paratypes: $50^{7} \sigma^{7}, 290,36$ ex. «AKR/ Jan. 2016 | N MADAGASCAR Mahamasina vill. env. light trap 26.1.2016; P. Baňař lgt.» (MMBC; 2 ex. - BMNH; 2 ex. MHNG; 2 ex. - NHMW; $10^{7}, 19,8$ ex. - cMG).

Description. Holotype. Length $1.7 \mathrm{~mm}$. Head and abdomen dark brown, with reddish tint; pronotum and elytra brown, with reddish tint; legs and antennal bases yellow brown; antennae darkened toward apex to dark brown. Integument rather shining, body with short, light-coloured hairs.

Head transverse, with a wide base, ratio of its length (from posterior margin of head to anterior margin of clypeus) to maximum width about 16:24. Neck constriction prominent. Eye large, convex. Temples well-developed, round, eye diameter in dorsal view about 2.5 times as large as temple length. Head widest across eyes (Figs 3, 4). Head surface with rather distinct, fine and sparse punctation on smoothly shagreened background. Puncture diameter about 3.5 times as small as eye facet, distances between puncture significantly larger than their diameter, interspaces shagreened, rather shining. Antennae short, segments 1-3 elongate; segment 4 about as long as wide; segments 5-7 slightly transverse; segments 810 transverse; segment 11 elongate, conical. Last 3 segments more massive than others and form loose club (Figs 3, 4).

Pronotum widest about $2 / 3$ its length from base, then narrowed. Lateral margins with a small notch at base, then smoothly rounded (Figs 3, 4). Ratio of pronotum length to tis maximum width about 19:24. Surface of pronotum with rather distinct, fine and sparse punctation on smoothly shagreened background. Puncture diameter about 3.5 times as small as eye facet, distances between punctures significantly larger than their diameter, interspaces shagreened, rather shining. Pronotal disc with 1 pair of rather weak, symmetrical, longitudinal, bean-shaped depressions separated by narrow medial ridge lacking punctation (Figs 3,4).

Ratio of length of elytra to their combined width about 29:32. Scutellum with weak round depressions (Figs 3, 4). Surface of elytra with distinct, rather large and dense punctation on smoothly shagreened background. Puncture diameter 


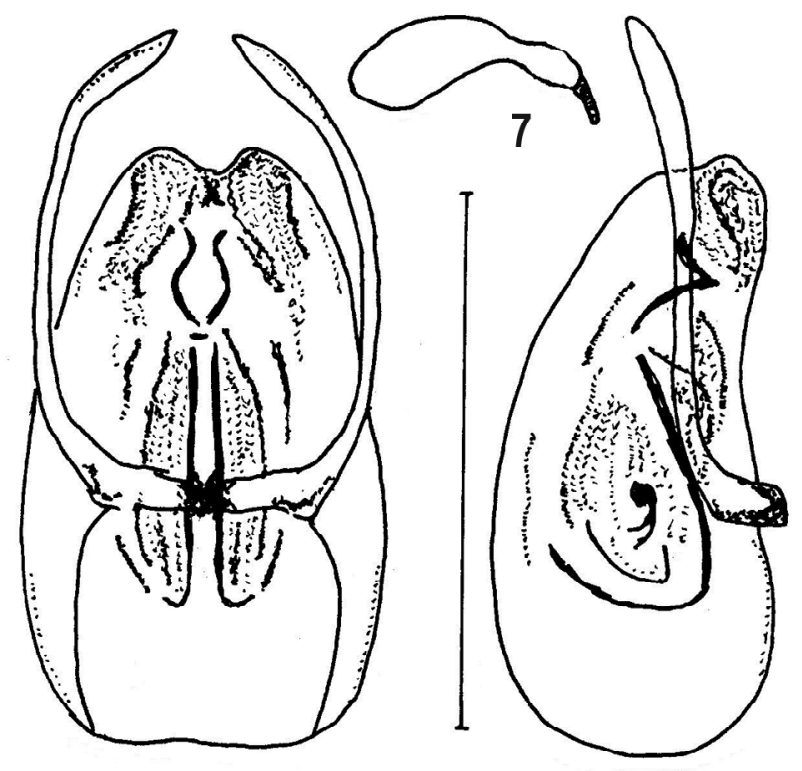

5
6

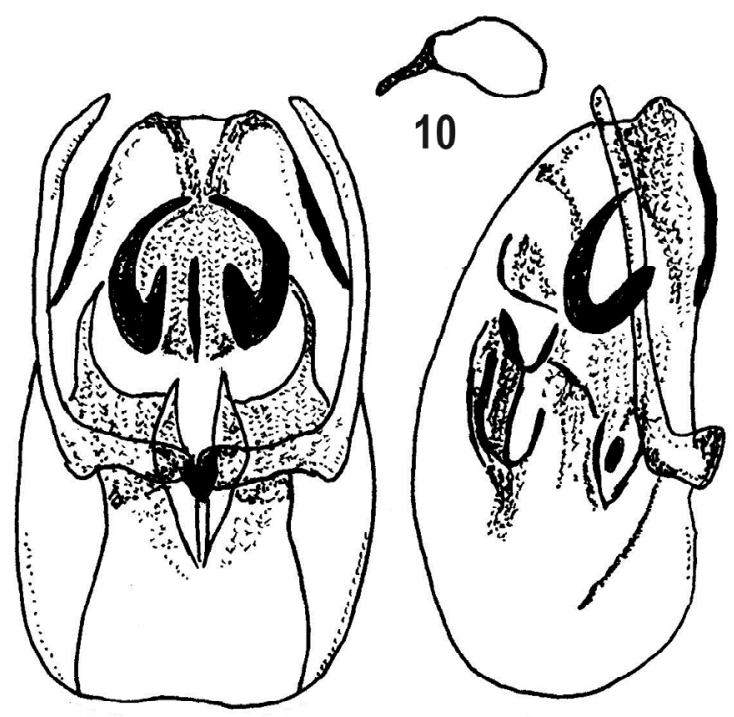

8

Figs 5-10. Carpelimus spp.: 5 - C. mahamasiensis, sp.n., holotype, aedeagus, ventral view; 6 - C. mahamasiensis, sp.n., holotype, aedeagus, lateral view; 7 - C. mabamasiensis, sp.n., paratype, spermatheca; 8 - C. banari, sp.n., holotype, aedeagus, ventral view; 9 - C. banari, sp.n., holotype, aedeagus, lateral view; 10 - C. banari, sp.n., paratype, spermatheca. Scale bar: 0.25 mm.

Рис. 5-10. Carpelimus spp.: 5 - C. mahamasiensis, sp.n., голотип, эдеагус, снизу; 6 - С. mahamasiensis, sp.n., голотип, эдеагус, сбоку; 7 - C. mahamasiensis, sp.n., паратип, сперматека; 8 - C. banari, sp.n., голотип, эдеагус, снизу; 9 - C. banari, sp.n., голотип, эдеагус, сбоку; 10 - C. banari, sp.n., паратип, сперматека. Масштабная иинейка: 0,25 mm.

about equal to eye facet. Distances between punctures slightly smaller than their diameter, interspaces shagreened, rather shining (Figs 3, 4).

Abdomen delicately shagreened.

Aedeagus of characteristic structure (Figs 8, 9).

Female. Sexual dimorphism absent, female morphologically similar to male.

Spermatheca of characteristic structure (Fig. 10).

Differential diagnosis. The new species is similar and closely related to Carpelimus (Trogophloeus) kunenensis Gildenkov, 2013 and Carpelimus (Trogophloeus) snizeki Gildenkov, 2013, but differs in its brighter colouration, pronounced punctation on the head and pronotum and in the geographical distribution. The new species can be clearly distinguished by the details of the structure (Figs 8,9 ) of aedeagus [Gildenkov, 2013a: P.280: fig.2: 1-4; Gildenkov, 2015: P.393: fig.27: 10, 12].

Distribution. North of Madagascar.

Etymology. The species is named after Petr Baňař (specialist in Hemiptera, Moravian Museum in Brno) who collected the type series.

\section{Acknowledgements}

The author expresses profound gratitude to the curators of collections and the colleagues for the providing of material examined: Petr Baňař (Strá nice, Czech Republic) and Jiri Janák (Rtyně nad Bílinou, Czech Republic). I also thank Kirill Makarov (Moscow Pedagogical State University, Moscow) for taking the photographs.

\section{References}

Gildenkov M.Yu. 2007a. Obzor fauny podroda Carpelimus (s.str.) (Coleoptera, Staphylinidae) Tropicheskoy Afriki // Zoologichesky Zhurnal. Vol.86. No.9. P.1073-1085. [In Russian, with English summary].

Gildenkov M.Yu. 2007b. Obzor fauny podroda Troginus roda Carpelimus (Coleoptera, Staphylinidae) Tropicheskoy Afriki // Zoologichesky Zhurnal. Vol.86. No.11. P.1315-1327. [In Russian, with English summary].

Gildenkov M.Yu. 2011. Novyj vid Carpelimus Leach, 1819 iz Palearktiki i dopolnenija k obzoru fauny podroda Carpelimus (s. str.) Tropicheskoj Afriki (Coleoptera, Staphylinidae, Oxytelinae) [A New Species of the Staphylinid Genus Carpelimus Leach, 1819 from Palaearctic and Additions to the Review of Fauna of Subgenus Carpelimus (s.str.) from Tropical Africa (Coleoptera, Staphylinidae, Oxytelinae)] // Izvestiya Smolenskogo Gosudarstvennogo Universiteta. No.4(16). P.64-72. [In Russian, with English summary].

Gildenkov M.Yu. 2012. Predvaritelnyj obzor podroda Bucephalinus Koch, 1934 iz roda Carpelimus Leach, 1819 dlja Tropicheskoj Afriki (Coleoptera, Staphylinidae, Oxytelinae) [A Preliminary Review of the Subgenus Bucephalinus Koch, 1934 from Genus Carpelimus Leach, 1819 for Tropical Africa (Coleoptera, Staphylinidae, Oxytelinae)] // Izvestiya Smolenskogo Gosudarstvennogo Universiteta. No.3(19). P.245-256. [In Russian, with English summary].

Gildenkov M.Yu. 2013a (2012). Novye vidy podroda Trogophloeus Mannerheim, $1930 \mathrm{iz}$ roda Carpelimus Leach, $1819 \mathrm{dlja}$ Tropicheskoj Afriki (Coleoptera, Staphylinidae, Oxytelinae) [New Species of the Subgenus Trogophloeus Mannerheim, 1930 from Genus Carpelimus Leach, 1819 for Tropical Africa (Coleoptera, Staphylinidae, Oxytelinae)] // Izvestiya Smolenskogo Gosudarstvennogo Universiteta. No.4(20). P.266-294. [In Russian, with English summary]. 
Gildenkov M.Yu. 2013b. Obzor sostava podroda Trogophloeus Mannerheim, 1930 iz roda Carpelimus Leach, 1819 dlja Tropicheskoj Afriki (Coleoptera, Staphylinidae, Oxytelinae) [The Review of the Structure of the Subgenus Trogophloeus Mannerheim, 1930 from Genus Carpelimus Leach, 1819 for Tropical Africa (Coleoptera, Staphylinidae, Oxytelinae)] // Izvestiya Smolenskogo Gosudarstvennogo Universiteta. No.1(21). P.242-251. [In Russian, with English summary].
Gildenkov M.Yu. 2015. Fauna Carpelimus Starogo Sweta (Coleoptera: Staphylinidae) [Fauna Carpelimus of the Old World (Coleoptera: Staphylinidae) - Smolensk: SmolSU. 414 p. [in Russian with English summary].

Gildenkov M.Yu. 2019. New species of the genus Carpelimus Leach, 1819 (Coleoptera, Staphylinidae, Oxytelinae) from South Africa // Evrasiatskii Entomologicheskii Zhurnal [Eurasian Entomological Journal].Vol.18. No.5. P.355-356.

Поступила в редакцию 16.11.2019 